body, while considering fraud and other serious matters in the context of individuals faced with disqualification from employment in the financial services industry, is not determining criminal guilt. Judges sitting with experts are not uncommon in the civil jurisdictions of common law courts, but in criminal jurisdiction it is quite a radical step.

\section{JUDGE WITH JURY LATER}

It is the fourth option discussed that is perhaps the most unusual and marks the most radical departure from our accepted concepts of criminal law and the respective functions of judge and jury. This is described as trial by a single judge with a jury for key decisions. It is envisaged that the trial would have three broad stages. The first would consist of the judge identifying the issues. The authors consider this would shorten the process, because it would prevent the need for pre-trial evidential rulings, as the second stage would consist of the judge making determinations of fact. At this second stage the judge would deal with the factual issues; the authors equate this to the present summing-up, but it is obviously far more than this. The judge would make findings of fact but would not determine guilt. The final stage would consist of the jury being sworn in and the judge then explaining the case to them. The jury would then be asked to determine whether the conduct amounted to dishonesty or whether inferences could be drawn that a defendant had requisite knowledge or had behaved recklessly.

The extreme difficulties of this unusual approach are highlighted in the paper which acknowledges that the judge's finding on the factual issues may need to be supplemented by evidence from the defendants explaining themselves, or even additional evidence from key witnesses! It would appear likely that this alternative will be the least likely to receive support.

In the New Law Journal, 20 February 1998, Robert Rhodes QC deplored the suggestion of doing away with jury trials for serious fraud. His article contains trenchant criticisms of the proposals in the Home Office consultation paper. However, serious fraud trials do create problems of length and size and it is proper that those difficulties be debated. It is to be hoped though, that such a fundamental change as denying the right to jury trial would only come about from reasoned debate with full regard to the rights of defendants. It would be wrong if it came about because of certain well-publicised, unsuccessful prosecutions.

There is the added danger that it could be the thin end of the wedge. Very complicated evidence can arise in other areas as well. In New Zealand there was a highly publicised attempted murder trial. It was an allegation of poisoning against a jilted lover. Both parties were academics and the victim enjoyed a worldwide reputation in his field. The poison allegedly used was extremely rare. Experts from around the world gave evidence for prosecution and defence. The nature of their evidence was extremely complex, probably more so than that given in most complex fraud trials. Should cases such as this have some special procedure? Why should a special procedure apply only to fraud cases with complex evidence and not to other criminal charges with equally complex evidence? These are critical questions that need to be examined with very great care before something as fundamental as the right to trial by jury is lost.
John Hansen

Mr Justice Hansen, Executive High Court Judge, New Zealand

\title{
The best way forward in fraud trials?
}

\author{
by Christopher W Dickson
}

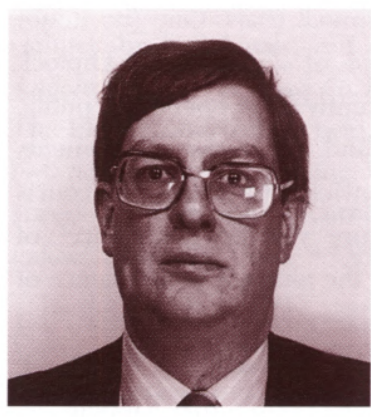

Much could be done to improve existing jury trials, believes Christopher Dickson, who looks at the background to the consultation document on the future of juries in serious fraud trials, and discusses the possible outcome.

$\mathrm{T}$ he recent Home Office consultation document on the future of juries in serious fraud trials has been characterised by some as an attempt to ensure that the high profile Serious Fraud Office defeats of the past are not repeated in the future. I do not believe that this is its purpose. Contrary to popular perception the Serious Fraud Office's record is a good one: most recently a $94.4 \%$ conviction rate since April 1997, with a 'lifetime' rate of over 70\%. It is a record which stands comparison with those of comparable prosecutors anywhere, reflecting as it does some of the most difficult and complex criminal cases ever tried. I do not believe it would have been significantly different, taken over the last ten years, whatever alternative mode of trial had been in operation.

What is really behind the Home Office document is a desire 
by the Treasury to contain the spiralling cost of long fraud trials.

The suggested alternatives to the present system, upon which comment is invited, range from the eminently sensible (some form of additional screening of jurors), through the predictable (a fraud tribunal consisting of a judge with lay members), to the frankly bizarre (a judge to hear the evidence, with a jury being brought in at the end to listen to the judge's findings of fact and determine such issues as the defendant's honesty or otherwise).

\section{IMPROVING JURY TRIALS}

There is no doubt that much could still be done to improve jury trial. First, is there any real justification (other than their own convenience) for disqualifying or excusing as of right so many apparently intelligent people from jury service? For example, barristers and solicitors are disqualified; MPs, members of the House of Lords, and practising medical practitioners may be excused as of right. These disqualifications and exemptions should mostly be abolished (as has happened recently in New York state), with judges thereafter being very slow to excuse any person from serving on the ground of inconvenience, balanced by proper reimbursement of lost earnings.

Secondly, whilst I appreciate that it is more easily said than done, I believe that some form of screening of jurors as to their level of education and/or aptitude should be introduced. The principal proponent of this idea has been John Wood, the first Director of the Serious Fraud Office and later Director of Public Prosecutions in Hong Kong. He has suggested a standard of competence in English and mathematics. Would it really be beyond the bounds of acceptability to devise such a standard, based perhaps on GCSE A-C grades or their equivalent in English and mathematics, with a short aptitude test as a possible alternative? Jurors in serious fraud cases already fill in questionnaires to ensure that they have no connection with the subject matter of the case to be tried, so a small number of additional questions should not cause any great difficulty.

Thirdly, the American practice of swearing in 'alternate jurors' should be seriously considered. Sickness among one or more of the twelve jurors is almost inevitable in a long trial, particularly during the winter. Most long trials have lost, overall, several weeks to sickness, because judges are understandably slow to discharge jurors if there is a risk of having to start the trial again (the minimum size to which a jury can drop is nine). The alternative - adjourning the trial in the hope of recovery - is time-consuming and expensive. If a proposal for alternate jurors were to be adopted, it would be worth considering whether identification of the twelve jurors who were actually going to consider the verdict should be deferred until the end of the trial (assuming that there were still more than twelve jurors left), when there could be a ballot of those remaining. Otherwise, the alternates might have no incentive to pay attention.

The most significant antidote to the problems of long trials jury boredom and demoralisation - would be a corps of pro-active specialist fraud judges, determined to push cases along and prevent time-wasting manœuvres by defence counsel. There are such judges, but they are naturally much in demand and are quickly promoted to appellate work.

\section{TRIAL BY JUDGE ALONE}

The principal alternatives to jury trial suggested in the consultation document are either to have a judge sitting alone, or to adopt Lord Roskill's recommendation of a fraud tribunal presided over by a judge sitting with lay members. Both of these suggestions have their merits. Trial by judge alone (albeit in a very different type of case) has worked well in the Diplock Courts in Northern Ireland. In part, this is a tribute to the high quality of the Northern Ireland judiciary which, like its Scots equivalent, has a collegiate quality which comes of being small in number. One wonders how the much larger and more disparate English judiciary would manage. Criticism of the decisions or workings of the Diplock Courts is seldom heard from practising lawyers in Northern Ireland, and there has been a notable absence of cases giving rise to public concern of the kind which have so damaged the English criminal justice system. A particular benefit to defendants is the requirement that the judge must produce a reasoned judgment explaining why he has reached his conclusions. Such judgments have proved more fruitful sources of appeal than the simple fact of a jury verdict.

\section{FRAUD TRIBUNAL MOST LIKELY}

A fraud tribunal consisting of a judge sitting with lay members also has something to commend it. The theory is that the lay members would have, for example, particular financial or accountancy expertise. The great danger of such an arrangement is that the lay members will be tempted to decide cases not on the basis of the evidence which they hear, but rather from their own specialist experience.

With the present law officers at Buckingham Gate, nothing will have been pre-judged. But I sense that Treasury voices will be sufficiently powerful to make the fraud tribunal option the most likely outcome. This would be a mistake, however well-intentioned. First, it would represent a major crack in the ramparts of jury trial: it would not be long before politicians, with an eye to the bottom line, started to ask: if a man who relieved a bank of $£ 1 \mathrm{~m}$ using a computer was tried by a tribunal, why could a man who did the same thing using a shotgun not be tried in the same way?

Secondly, and even more seriously, the long-term consequences of trial by fraud tribunal would be to impugn the very legitimacy of such trials as criminal trials. One (no doubt originally unintended) consequence of 25 years of Diplock Courts in Northern Ireland has recently been opened to public gaze in the prisons of Northern Ireland. Successive governments have tacitly conceded that those convicted by judge-only courts are 'prisoners of war' whose future will be the subject of bargaining in 'peace' talks. I believe the ultimate consequence of fraud tribunals would not be 'prisoner power' taking over Ford Open Prison (some would say it already has!), but rather the decriminalisation of serious fraud itself. When that happens, all pretence at deterrence will have gone.

\section{W Dickson}

Executive Counsel, Accountants' Joint Disciplinary Scheme; formerly Senior Assistant Director, Serious Fraud Office 